This is the accepted version of an article published in the peer-reviewed journal Critical Sociology, doi:10.1177/0896920514526623. For the version of record visit:

http://crs.sagepub.com/content/early/2014/06/02/0896920514526623?papetoc

\title{
Opportunities and limitations for collective resistance arising from volunteering by asylum seekers and refugees in Northern England
}

Tom Vickers, Northumbria University, UK

tom.vickers@northumbria.ac.uk

\section{Abstract}

This article asks whether volunteering by refugees and asylum seekers holds potential to foster collective resistance to the British state's increasingly punitive asylum policies. It draws on research that included four organizational case studies and in-depth qualitative interviews with refugees and asylum seekers volunteering in a city in Northern England, and analyses this data using interrelated concepts of contradiction, hegemony and social capital. This research found that volunteering by refugees and asylum seekers had potential to contribute to cohesive social blocs that might form a basis for resistance, yet also exhibited tendencies to divide refugees and encourage individualised forms of action, which reinforced a subordinate position for the majority. The article concludes that realizing the potential of voluntary activity as a basis for collective resistance to the state's asylum policies may require it to be combined with political education and organization.

\section{Keywords}

Marxism, hegemony, collective action, social capital, state 
This is the accepted version of an article published in the peer-reviewed journal Critical Sociology, doi:10.1177/0896920514526623. For the version of record visit:

http://crs.sagepub.com/content/early/2014/06/02/0896920514526623?papetoc

\section{Introduction}

This article develops a Marxist approach to social capital to explore contradictory tendencies within volunteering by refugees ${ }^{1}$ in a city in Northern England.

Refugees arrive in Britain with backgrounds often including trauma, abuse and serious health problems. Increasingly since 1999, the British state has compounded refugees' problems through destitution, periodic detention, and the constant psychological stress of threatened deportation to situations of extreme danger. Between 1999 and 2010 the British government pursued a split approach, combining strategies of forceful assimilation with punitive segregation (Vickers 2012). For refugees without status in Britain this included, and continues to include, restricted access to many mainstream welfare services, a prohibition on paid work, and forced dispersal (Hynes, 2009; Crawley et al., 2011).

From the early 1990s, numerous voluntary sector organizations specifically targeting refugees were established across Britain (WLRI, 2005). While some voluntary sector organizations publicly criticised the dispersal process, there was no sustained campaign, and organizations from the voluntary sector, and in some cases Refugee Community Organizations (RCOs), ultimately took the front line in implementing dispersal, either directly through government contracts, or indirectly through partnerships with the police and local authority asylum teams (Briskman and Cemlyn, 2005; Hynes, 2009).

In 2002 the prohibition of paid work for the majority of refugees without status gave a major boost to volunteering. The 2005 Home Office document Integration Matters: $A$ National Strategy for Refugee Integration directed specific attention to volunteering by refugees with leave to remain, arguing this was an important route to integration. Faced with scarce resources, many organizations working with refugees came under pressure to make use of refugees' voluntary labour (Evelyn Oldfield Unit, 2004). For example, in the case of VOL, an organization delivering services contracted from the Home Office that is discussed further below, a survey I conducted of volunteer records for two six-month 
This is the accepted version of an article published in the peer-reviewed journal Critical Sociology, doi:10.1177/0896920514526623. For the version of record visit:

http://crs.sagepub.com/content/early/2014/06/02/0896920514526623?papetoc

periods between 2005 and 2007 showed that fluctuations in demand for services were met largely by an increase in the total hours worked by volunteers, half of whom were refugees.

Hardill et al. (2007: 397) suggest volunteering holds significance within processes of social control and resistance, because it 'is situated at, and builds bridges between, three levels: the community, the voluntary organization and the individual'. This article explores the potential for resistance to state policies to emerge among refugees volunteering in the context described above. The first section considers the utility of 'social capital' within a Marxist approach, as a way of understanding how capitalist hegemony - the dominance of capitalist ideas, norms and values - is sustained and contested at an individual and interpersonal level. This engagement with social capital theory is also an exercise in resistance, by attempting to turn social capital concepts back against those neo-liberal forces that have promoted them. Against Fine's (2010) argument that 'whilst a Marxist (or other) version of social capital might deliver appropriate insights, these would certainly be lost among the orthodox juggernaut of contributions that dominate the literature' (155-6), this may be said of any ideas that seek to challenge capitalist hegemony. I pose the question of whether co-option of concepts is only possible for the ruling classes, as with 'empowerment', 'participation' (Shaw and Martin, 2000), and 'community organizing' (Mills and Robson, 2010), or whether there are situations where social capital might be coopted to serve the interests of the working classes. The second section tests this in the case of refugees volunteering, using empirical data. After presenting the research methodology, the article considers spontaneous tendencies towards the formation of 'oppositional social capital' within volunteering by refugees, followed by discussion of countervailing tendencies. The inter-related concepts of contradiction, social capital and hegemony form a conceptual thread running through this discussion. The article concludes 
This is the accepted version of an article published in the peer-reviewed journal Critical Sociology, doi:10.1177/0896920514526623. For the version of record visit:

http://crs.sagepub.com/content/early/2014/06/02/0896920514526623?papetoc

that volunteering within the context of the UK asylum system has the potential to both draw refugees together and to throw them apart, and that realizing the oppositional potential within spontaneous collectivist tendencies produced by volunteering may call for political education and organization. 
This is the accepted version of an article published in the peer-reviewed journal Critical Sociology, doi:10.1177/0896920514526623. For the version of record visit:

http://crs.sagepub.com/content/early/2014/06/02/0896920514526623?papetoc

\section{Social capital}

Since the 1990s the term 'social capital' has attracted massive attention, both inside and outside academia, 'explaining' diverse phenomena including health outcomes, child poverty and political participation. Social capital is an elastic, contested term, covering diverse perspectives relating to non-contractual mechanisms by which groups and individuals negotiate access to social and material resources (Griffiths, et al., 2005: 34). One definition, used by the UK Office for National Statistics, describes social capital as 'the pattern and intensity of networks among people and the shared values which arise from these networks' (cited in Wilson and Lewis, 2006: 16). A comprehensive survey of the concept is beyond the scope of this article. However, it is necessary to situate my approach in relation to social capital's most famous theorist, Robert Putnam. For Putnam (2000), social capital refers to bonds of mutual trust and reciprocity fostered by voluntary association between people outside state and market relationships, which act as a 'superglue' holding individuals together and encouraging trust and cooperation with the state. This links civil society with rational choice theory, offering a measure of social cohesion and voluntary cooperation to cushion class confrontations provoked, for example, by job losses and the withdrawal of state welfare provision (Das, 2006: 85-6). Reinforcing this, social capital theorists have often ignored protest movements and other conflictual mobilizations, which implicitly problematise the relationship between civil society and the state (Mayer, 2003: 117-18; also Das, 2006: 71). Putnam's ideas have been promoted by powerful agents of neo-liberalism², including the World Bank and the 19972010 British Labour government, to locate blame for poverty within the deficits of poor communities and absolve powerful people and structures (Fine, 2010 provides a detailed critique).

Social capital theorists have often neglected context, and when they have acknowledged its importance (e.g. Furbey, et al., 2006), they have often still operated on 
This is the accepted version of an article published in the peer-reviewed journal Critical Sociology, doi:10.1177/0896920514526623. For the version of record visit:

http://crs.sagepub.com/content/early/2014/06/02/0896920514526623?papetoc

the basis of a uniform type of social capital, but producing different outcomes depending on the context 'it' exists in, or the degree of access to, or possession of, social capital by different parties. To more fully appreciate the differences of each context, as part of reconceptualising social capital within a Marxist framework, it may be helpful to speak of 'social capital formations', as dynamic social structures carrying particular norms and values and involving actors who may occupy different positions within the formation in terms of their influence on the formation and its implications for their interests. This is similar to Reed's (2013) conception of 'ideological orders':

as active conceptions of the world - i.e. fluid social formations - with roots in the lived realities of its collective (but also individual) possessors. They are by definition socio-historical conceptions that mutually reinforce each other to varied degrees, in varied configurations, at different times in history, and operate, more often than not, to give solidity to the dominant practices of society. (Reed 2013: 564)

The concept of social capital formations captures the inter-relationships between: networks; the class position of actors within these networks, in terms of both their objective relationship to the means of production and their subjective identity; and ideological processes within these networks, expressed through norms and values.

I do not argue that there can be a social capital theory of society, but with Das (2006) that 'within a class theory of society, social capital can play some role', as an 'investigative category' (83), and pursue the project he proposes, to 'unpack the opportunities of -and, more importantly, limits to-social capital as they are rooted in class, in specific places and over space' (72-3), including the emergence of norms and values as 'collective properties that transcend individual experiences' (Devine and Roberts, 2003: 94).

\section{Developing a Marxist approach to social capital}

It is beyond the scope of this article to discuss Marxist sociology in any detail, and would 
This is the accepted version of an article published in the peer-reviewed journal Critical Sociology, doi:10.1177/0896920514526623. For the version of record visit:

http://crs.sagepub.com/content/early/2014/06/02/0896920514526623?papetoc

likely be unnecessary for readers of Critical Sociology. I take a Leninist approach, as expressed in the Philosophical Notebooks (Lenin, [1895-1916] 1972). Compared to other, sociological, approaches to class, Leninism is one school of Marxism that focuses attention on the impact of class struggles on the maintenance and disruption of the class system, and understands the capitalist state as a means of holding in check irreconcilable class antagonisms in order to create stable conditions for exploitation (Lenin, [1917] 1972: 8). In this view the state represents the economically dominant class, who, through the exercise of a state apparatus specifically tailored to its needs, maintains its political domination (1314), backed up by an exclusive claim to the legitimate use of violence. This is not to deny contradictions within the state, with welfare provision frequently representing both hardwon resources for the working classes and a means of social control (Jones and Novak, 1999; Stevenson, 1978) and state personnel developing, at times, a critical perspective on their role (LEWRG, 1980; Lavalette, 2011). Such contradictions are a central focus of this article, in particular at the fringes of the state as it engages with the voluntary sector. Yet despite such contradictions, the underlying dynamic and overall tendency of the capitalist state are to maintain capitalist class rule.

I recognise that the state does not operate simply through direct repression, and I draw on Gramsci's ([1929-1935] 1982) analysis of the dialectical relationship between consent and coercion in the modern capitalist state (Davies, 2011: 105-6). This includes the concept of 'hegemony', used by Lenin to describe a revolutionary strategy in which the working classes assume political leadership of other classes, and expanded by Gramsci to explain the ideological domination by the capitalist class over the whole of society. The two forms of hegemony differ in that capitalist hegemony dampens the conflicts arising from the worker-capital contradiction by disrupting working-class resistance, whereas working-class hegemony is part of a process of developing the worker-capital contradiction to the full in order to overthrow capitalist relations and resolve the worker- 
This is the accepted version of an article published in the peer-reviewed journal Critical Sociology, doi:10.1177/0896920514526623. For the version of record visit:

http://crs.sagepub.com/content/early/2014/06/02/0896920514526623?papetoc

capital contradiction through a new form of society, socialism (Lenin, [1902] 1978).

The phase of international capitalism that emerged in the late nineteenth century and continues to the present is defined by Lenin ([1916] 1975) as imperialism, involving the division of the world, at a high level of abstraction, into oppressed and imperialist countries (Petras and Veltmeyer 2001). It is therefore necessary to address not only the worker-capital contradiction in general, but the particular interests of the national capitalist class of each country. It is beyond the scope of this article to demonstrate Britain's imperialist character (see Vickers 2012), but it needs to be stated that when I speak of 'capitalist hegemony', I do not mean the hegemony of capitalist ideas in general, but of those reflecting British capitalist interests in particular, which depend on the exploitation of the labour and natural resources of oppressed countries.

Marxists have taken a variety of approaches to social capital. Prior to its neo-liberal incarnation, Pierre Bourdieu (1995) conceptualised social capital as part of the reproduction of class society, alongside economic, cultural and symbolic capital. While my definition shares Bourdieu's emphasis that social capital only exists in its production and reproduction (also Anthias, 2007: 791), I disagree with Bourdieu's concept of social capital as one of several types of capital, and agree instead with Das (2006), who cautions:

Strictly speaking, these social resources [that constitute social capital] are not capital, and they are referred to as capital here solely in a metaphorical sense, since capital proper is an exploitative relationship between capital and labour, and resources only become 'capital' in this relationship. (65, emphasis in the original)

Das (2006) draws on Woolcock's (1998) analysis, of social capital as constituted by social relations, to argue that if class constitutes the most important determining factor of these social relations, then it follows that there are different kinds of social capital for different classes. The difference between working-class and capitalist social capital lies in capitalists' reliance on primarily private political power - ownership of the means of 
This is the accepted version of an article published in the peer-reviewed journal Critical Sociology, doi:10.1177/0896920514526623. For the version of record visit:

http://crs.sagepub.com/content/early/2014/06/02/0896920514526623?papetoc

production - and workers' reliance on public political power - political self-organization (Das, 2006: 70-71). This connects with the difference outlined above, between capitalist hegemony - whose purpose is to dampen class contradictions - and working class hegemony - whose purpose is to develop class contradictions to the full in order to supersede them. As Lenin ([1895-1916] 1972) argues, the capitalist and working classes are interdependent and both alienated within capitalism, but the capitalist class "feels happy and confirmed in this self-alienation, it recognises alienation as its own power, and has in it the semblance of human existence", while the working class "feels annihilated in its self-alienation; it sees in it its own powerlessness and the reality of an inhuman existence" (26-7, emphasis in the original). From this arises a conservative impetus on the part of the capitalist classes, towards preserving this relationship, and a destructive impetus on the part of the working classes, towards annihilating the same relationship. It follows that for the capitalist class to neutralise working-class resistance, it must interfere in the development of their public political power, by undermining the development of working-class social capital and incorporating working-class people into social capital formations that embody the ideas of the capitalist class. This is one example of how the economically dominant class, by dint of their control of a state apparatus tailored to their needs, make the ideas that reflect their class interests the dominant ideas of society as a whole (Marx and Engels, [1845] 1991: 52-3). In this article I extend this reasoning to argue that where experiences of housing, employment and welfare provision are shaped by immigration controls, this lays the basis for particular kinds of social capital among refugees.

Examining processes of social capital formation, disruption and reformation is one way to explore how distinct norms, values and identities based around working-class interests may be expressed and sustained. By establishing at least partial independence from capitalist hegemony, social capital formations may contribute to what Lenin termed 
This is the accepted version of an article published in the peer-reviewed journal Critical Sociology, doi:10.1177/0896920514526623. For the version of record visit:

http://crs.sagepub.com/content/early/2014/06/02/0896920514526623?papetoc

'historical blocs', involving different 'economic, social, and ideological forces combined in a temporary unity to change society' (McLellan, 1980, 184-5). The concept of 'oppositional social capital' is mentioned briefly by Body-Gendrot and Gittell (2003: xiii) and employed by Das (2006) in discussing 'working-class social capital', and has relevance for discussing the incorporation and resistance of refugees in Britain. Social capital interventions were used by Labour governments between 1997 and 2010 to paper over material inequalities and manage oppression (Mayer, 2003; 6, et al., 2010). Encouragement for volunteering played a prominent role, as part of government-voluntary sector compacts established in 1998. These agreements set out a role for charities in to participate in the governance of society, and reconceptualised "the community as a mobilising focus for collective action in a way that links 'the sturdy "self-reliance" of the past' (drawing upon nostalgia for traditional working-class communities) with the "active citizenry" of community action in the present'"' (Morison, 2000: 109-10). Refugees represented one of the most oppressed groups in Britain during the 1997-2010 Labour government and continuing to the present, with antagonism from the British state rooted in international divisions of labour within imperialist capitalism, which assign a subordinate position to migrants from underdeveloped countries (Foster et al., 2011). Neo-liberal capitalist policies have increasingly promoted labour market demand as the exclusive ideal for deciding rights to residence, and consequently universalist claims to safety from persecution are viewed as a threat (Vickers 2012). This creates the material basis for an acute contradiction between refugees and the British state, with the potential to stimulate resistance which the state must attempt to manage.

For oppressed groups such as refugees, social capital may prove both a necessary part of their oppression and something that may be transformed into a weapon capable of opposing other, more physical elements of repression. This echoes long-established ideas of collective organization based on shared interests, trust, and solidarity, to overcome 
This is the accepted version of an article published in the peer-reviewed journal Critical Sociology, doi:10.1177/0896920514526623. For the version of record visit:

http://crs.sagepub.com/content/early/2014/06/02/0896920514526623?papetoc

oppressive forces possessing far greater material resources (Shucksmith, 2000: 216). Some forms of opposition are overt, based on forms of organization that are self-consciously political and independent of the state (Però 2008; Vickers 2014). Yet resistance may take many forms (Papadopoulosa and Tsianosb, 2013), and sometimes originates in unexpected places. This article explores possibilities and limitations of oppositional social capital developing spontaneously within the very mechanisms the state uses to manage refugees' oppression, in this case state-sponsored or -endorsed voluntary sector organizations. 
This is the accepted version of an article published in the peer-reviewed journal Critical Sociology, doi:10.1177/0896920514526623. For the version of record visit:

http://crs.sagepub.com/content/early/2014/06/02/0896920514526623?papetoc

\section{Methodology of the empirical research}

This article draws on a study funded by the ESRC in the UK between 2007 and 2010, which combined in-depth semi-structured interviews and focus groups, historical and newspaper archives, theoretical literature and statistical data on movements of people and capital. The overall study aimed to investigate relationships between experiences, consciousness and action among refugees engaged in voluntary activity. Formal generalizations about the nature and extent of social capital based on quantitative methods frequently fail to account for a specific context's unique features, including contradictions (Roberts, 2004: 473). The impact of factors such as 'moral motivations' on voluntary activity are especially difficult to capture using quantitative methods (John, et al., 2011: 233-4). Qualitative methods were used to overcome these difficulties.

This article focuses on one aspect of the study, using refugees' accounts gathered through interviews and focus groups in Newcastle upon Tyne, North East England (other findings on the economic interests shaping Britain's asylum policies, which employed statistical data, are reported in Vickers 2012). Eighteen refugees, who had been dispersed to Newcastle between 1999 and 2008, participated in twenty-four interviews and two focus groups between 2007 and 2010. Interviewees were accessed through four organizations where they were volunteering, which are referred to using anonymised acronyms: 'VOL', a large voluntary sector organization delivering contracts for the British government Home Office; 'COM', a refugee-initiated community advice/signposting organization; 'CHUR', a church-based voluntary sector organization delivering advice/signposting and a hardship fund; 'CAMP', an asylum-rights/anti-racist campaigning organization including refugees and British activists. Of the refugee volunteers interviewed, nine were men and nine women. These were distributed unevenly - all interviewees from CAMP were women and all interviewees from CHUR were men - but this reflected the gender balance within these organizations. At the time of the initial 
This is the accepted version of an article published in the peer-reviewed journal Critical Sociology, doi:10.1177/0896920514526623. For the version of record visit:

http://crs.sagepub.com/content/early/2014/06/02/0896920514526623?papetoc

interview, five interviewees had already secured some form of status. Of six refugees interviewed twice, an additional two had received some form of status by the second interview.

The first round of interviews with refugee volunteers used a set of questions informed by the literature, about past and present experiences of forced flight and settlement, the actions the individual had taken in response, and their plans and hopes for the future. Prior to the second round of interviews participants were asked to imagine they were writing a book about their life, and to decide what they would call each chapter. This structured the interviews, situating particular episodes of voluntary activity in Britain within the longer trajectory of each refugee's life (inspired by methods reported in WLRI, 2005). The first focus group was conducted in 2007 with refugees volunteering with VOL and solicited views concerning the British state and the asylum system. The second focus group took place in 2010 and included volunteers from CHUR, COM and CAMP who had been interviewed previously (efforts were made to invite VOL interviewees but they proved impossible to contact). This focus group was presented with a summary of emerging findings, and the discussion which followed was used for internal verification. This data was contextualised using academic and 'grey' literature, local press archives, annual reports and other organizational literature, and interviews with six individuals in management roles across the four organizations.

A cross-case analysis was conducted, between case organizations and between volunteers as embedded cases, to identify themes running through multiple cases, suggesting spontaneous tendencies in voluntary activity independent of an organization's aims, and differences between cases, pointing to tendencies specific to each organization's activities or structures. The small number of refugees volunteering with some of the organizations placed limits on the amount of contextual information provided alongside any direct quotation, to avoid identification of individuals by other research participants. 
This is the accepted version of an article published in the peer-reviewed journal Critical Sociology, doi:10.1177/0896920514526623. For the version of record visit:

http://crs.sagepub.com/content/early/2014/06/02/0896920514526623?papetoc

\section{Tendencies towards collective consciousness}

Gramsci ([1929-1935] 1982: 169-70) observes politics' 'dual perspective', with a dialectical relationship between the immediate and universal, and the potential for individuals' defence of their immediate physical existence to develop, via consciousness and a historical perspective, to an identification with 'the highest values of civilization and humanity'. Within socialist societies engagement in voluntary labour has formed an important part of such 'consciousness-raising', developing approaches to work as a collective social duty rather than a private material compulsion (Yaffe, 2009: 63-7). Refugees' accounts suggested potential for volunteering to develop wider collective identities and commitments, even in Britain under capitalist hegemony. This may represent one example where social capital 'can, to a degree, promote unity among working-class people, thus furthering their ability to confront the capitalist class and the state' (Das, 2006: 85-6). Some refugees reported beginning voluntary work from a lack of other options, but coming to appreciate non-material benefits such as the satisfaction of helping others:

I came to volunteer because...I was bored and stuff...But now the main reason is to gain experience of how to work with people...understand people, take time out of my own time. Because I think the best thing in life is to give your time up to some other people, to help them, and it's brilliant (VOL volunteer 1 )

In this situation the voluntary contribution of 'time out of [their] own time' creates a relationship producing use value through direct human contact and empathy, as an implicit challenge to the hegemony of alienated capitalist relations through waged commodity production. This suggests that the act of voluntary engagement itself carries the potential to change the nature of that engagement. The following discussion explores this further by considering evidence of social capital formations cultivated through volunteering, firstly among refugees and secondly between refugees and other sections of 
This is the accepted version of an article published in the peer-reviewed journal Critical Sociology, doi:10.1177/0896920514526623. For the version of record visit:

http://crs.sagepub.com/content/early/2014/06/02/0896920514526623?papetoc

the working classes.

Collective identities among refugees in the context of dispersal

When refugees without status began to be forcibly dispersed across Britain in 1999, little consideration was given to social and economic infrastructure or existing community networks or resources (Griffiths, et al., 2005: 41-2). Dispersal cut off refugees from family, friends, ethnic communities, services and support groups, and relocated them to areas with inadequate social provision, a lack of qualified lawyers, and high levels of exposure to racism (Briskman and Cemlyn, 2005: 718; Temple and Moran, 2005). This disrupted social capital formations, including those based around self-conscious diasporas, which pose an implicit threat to national borders (Gilroy, 2001: 124) and might have provided a basis for resisting incorporation into British capitalist hegemony.

Many refugees I interviewed reported new networks and trust driven by spontaneous factors including their isolation:

At that time [in 2000], there was not a lot of asylum seekers, we were all...very close, so...I would have an hour-long conversation with people from Iran, and neither of us would speak English (Cote d'Ivoire, arrived 2000)

This individual went on to engage in a range of organised activities working with people across national and cultural difference, in contrast to some other refugees, who began to build wider links out of necessity but later returned to linguistic-, religious- or nationalitybased forms of association as larger numbers and improved networks made these more viable. The same refugee reflected on their experience as a refugee without status, and the forms of engagement it led to, as an active learning process with long-term consequences, saying: 'being an asylum seeker forces you to open up...it just changed my whole thinking'. This is not to say that refugees I interviewed necessarily identified in a positive way as an 'asylum seeker', a category both widely denigrated and transitory. 
This is the accepted version of an article published in the peer-reviewed journal Critical Sociology, doi:10.1177/0896920514526623. For the version of record visit:

http://crs.sagepub.com/content/early/2014/06/02/0896920514526623?papetoc

Rather, the experience of being thrown together with people from diverse backgrounds, countries and languages, led to an 'opening up' and a willingness to form new identities across old barriers. The very fluidity of the identification as an asylum seeker provided a route to new collective identities, based variously around and sometimes intertwining geographically-based communities in working class localities, religious congregations, and anti-racist politics, with the potential for these to act as both frameworks for inclusion and bases of resistance to attempts by the state to deport or imprison individual members of the collective.

Several refugees I interviewed described incentives to volunteer operating more intensely because the people they were helping faced similar situations to themselves:

I think many people volunteer because it's...close to their heart since they've been in the process, they know how it works from personal experience, so they are...trying to give back to people who are in the same position (VOL volunteer 2)

This individual had progressed through a series of forms of activity, from helping immediate family members, to helping other refugees and migrants through VOL, and expressed hopes for the future to train professionally to contribute to wider struggles for social justice. In many cases shared experiences arising from their common position as refugees, facing the same contradictions with the British state, leads to a deeply emotional sense of solidarity ('close to their heart') and a desire to indirectly reciprocate help they have received from others. Such instances may be understood as 'bounded solidarity', representing social capital formations where actions are performed for non-instrumental reasons, motivated by group identification based on a perceived 'common fate' (Portes, 1998: 7-8).

Some refugees' accounts suggested potential for collective identities to move beyond their initial 'bounds', from defence of personal interests to wider identifications of shared interests, toward what Gramsci ([1929-1935] 1982: 204-5) calls 'compact social blocs', as a 
This is the accepted version of an article published in the peer-reviewed journal Critical Sociology, doi:10.1177/0896920514526623. For the version of record visit:

http://crs.sagepub.com/content/early/2014/06/02/0896920514526623?papetoc

basis for collective action, with potential to resist capitalist hegemony and oppose the state's actions. A recurrent theme among refugees' accounts was the role of volunteering in forming new networks, extending and consolidating these blocs:

if you work with the same people of your same community doing the same thing, you will learn their things and their language in their community...[But at VOL] there is a multiculture, there [are people] from around the world, from all countries (VOL volunteer 4)

The meaning of volunteering for this refugee was closely identified with exploring crossnational and cross-cultural diversity, as part of self-fulfilment and building new relationships. In some cases, volunteers described actively empathizing with other refugees they encountered as service users, leading to a stronger collective identity, as refugees and more broadly as newcomers to the city. Thus, volunteering has potential to do more than merely sustain itself, giving rise to new understandings and forms of activity. This represents the cultivation of norms and values of reciprocity and mutual support, taking on a particular character in the UK asylum context, with potential to contribute to the organic formation of the working classes (Das, 2006: 75), discussed in the following section.

\section{Building collective identities on the basis of shared material conditions}

The impoverished material conditions of the majority of refugees without status and many with status in Britain is well-documented (Crawley et al., 2011; Gillespie, 2012; Cuthill et al., 2013), and was reflected in the situations of refugees I interviewed. Although there were important differences between refugees and other sections of the working classes they lived alongside, sometimes formal and sometimes informal - including access to paid work, entitlements to residence and services - they nevertheless occupied the same side of the fundamental worker-capital contradiction, lacking ownership or control of the 
This is the accepted version of an article published in the peer-reviewed journal Critical Sociology, doi:10.1177/0896920514526623. For the version of record visit:

http://crs.sagepub.com/content/early/2014/06/02/0896920514526623?papetoc

means of production. Reflecting this, points of shared experience and living conditions formed the basis, in some cases, for social capital formations involving refugees and other sections of the working classes, as a refugee explained about the centre where he worked: we don't look at ourselves as only for Africans...nowadays we have more local [white British] young people coming in to play, to a certain level we realised even the local parent[s]...use us [to] take care of their children, when they pick their children up from school they just drop them [here], they know it is safe for them....we are part of this neighbourhood now...we're going [to]...the same GPs, we go to the same shops, we have the same problems (COM volunteer 1 )

In this case, organization among refugees became a trusted resource for wider sections of the working classes, and refugees volunteering with COM came to identify with the problems faced by others in the same geographical area, across racial and national divides.

In the context of barriers preventing refugees without status participating in many activities that would bring them into contact with non-refugees, such as paid work or accessing the same housing provider, interviewees suggested volunteering together played an important role in building links:

[I]f you come here to work and you don't have knowledge at all about immigration law and you don't know anything about asylum seekers, just what you hear on the TV, [volunteering] can really turn everything upside down. Because then you get in closer to people...if people don't know about it they see it as a big problem, all these asylum seekers and everything, they really see people just as leeches on the economy...many people don't even know that you're not permitted to work, many choose to think that...you just choose to be on benefits... whereas it's clearly not how it is. And people who come here [to volunteer] they kind of find it out (VOL volunteer 2) Another refugee felt the involvement of refugees without status in volunteering had an important potential to reverse negative perceptions by some British people of refugees 
This is the accepted version of an article published in the peer-reviewed journal Critical Sociology, doi:10.1177/0896920514526623. For the version of record visit:

http://crs.sagepub.com/content/early/2014/06/02/0896920514526623?papetoc

without status as 'spongers':

I think for [people looking at the project from] outside, it's just not British [volunteers] ...asylum seeker wants to help people, loves helping people, and just [to] volunteer...

because unfortunately people think...refugees without status [are] coming here for job or benefit (CHUR volunteer 2 )

This demonstrates the potential for volunteering, connected to both formal and informal social capital formations, to contribute to localised challenges to racist depictions of refugees that are hegemonic and backed by large sections of the media and government (Dummet, 2001).

\section{Volunteers as organic intellectuals}

Gramsci argues that the effective development of a counter-hegemonic project among oppressed groups requires the development of 'organic intellectuals' (Gramsci, [19291935] 1982: 204-5), arising from within oppressed groups and developing critical approaches from within existing cultural practice. Refugees volunteering to support other refugees hold such potential, and there was evidence of some gaining in confidence and assertiveness through their involvement, taking on roles in supporting the development of other refugees' understanding:

sometimes you will see someone saying 'You see, [people from your country], they will not deport you, your case is strong', but it's not true. My role is not just to tell to them [that it] is not true, we are still in danger. But also to explain to them when someone is doing this kind of thing to you, even you are an asylum seeker ... you still have your rights in this country. So for example if you are entitled to have accommodation, you need to have a suitable accommodation. (CAMP 6) The extent to which this role developed a critical distance from capitalist hegemony was influenced by wider organizational structures they were part of, individuals' perspectives 
This is the accepted version of an article published in the peer-reviewed journal Critical Sociology, doi:10.1177/0896920514526623. For the version of record visit:

http://crs.sagepub.com/content/early/2014/06/02/0896920514526623?papetoc

on their position over time, and their relationship to the state. These influences are explored below, through a discussion of countervailing tendencies within the volunteering process that encouraged refugees to adopt individualised forms of action. 
This is the accepted version of an article published in the peer-reviewed journal Critical Sociology, doi:10.1177/0896920514526623. For the version of record visit:

http://crs.sagepub.com/content/early/2014/06/02/0896920514526623?papetoc

\section{Tendencies towards individualised action}

VOL, COM and CHUR all demonstrated processes of social capital formation between refugees with and without status and other working-class people they lived alongside. Although this was, at times, based on shared political problems facing working-class areas, such as poor housing or lack of services, the kind of social capital evidenced above is not consciously political, but focuses on immediate provision of services, forming positive personal relationships and making the best use of what is already available, rather than mounting opposition or making demands. This leaves well-intentioned initiatives, with the interests of refugees at their heart, vulnerable to subversion in the face of powerful countervailing tendencies.

Individualizing tendencies, which undermined possibilities for resistance, arose from the community and organizational contexts where many refugees volunteered. Attention to these countervailing tendencies follows the approach of Das (2006), which he argues is distinctive...in recognizing the severe limits to working-class social capital formation-the limits as defined by the class structure' (82-3). In this case definitive aspects of the class structure include the position of refugees in Britain within international divisions of labour under contemporary capitalism (Foster 2011; Vickers 2012) and the overriding class character of the British state as defender of imperialist British finance capital. Across all organizations in my research, individualizing tendencies were apparent in the connection between volunteering and hopes of future paid employment and in the related tendency for some refugee volunteers to respond to a subjective class consciousness that was different from their current objective position. To differing extents in different organizations, these tendencies were underpinned by the financial and ideological penetration of communities and organizations by the British state.

The promise of paid work 
This is the accepted version of an article published in the peer-reviewed journal Critical Sociology, doi:10.1177/0896920514526623. For the version of record visit:

http://crs.sagepub.com/content/early/2014/06/02/0896920514526623?papetoc

Refugees I interviewed often connected voluntary activity with hopes of future paid employment. Healy et al. (2004) point to the impact of changes over recent decades, with work identities increasingly focused on individual careers rather than class membership. This forms part of the wider hegemony of neo-liberal ideas, which also impact on refugees. Amongst refugees, Lewis et al. (2013) report widespread conditions of precarious and exploitative labour, in some cases fitting ILO (International Labour Organization) criteria for forced labour, and suggest that these have been intensified by the absence of close-knit networks and an almost complete absence of collective strategies by refugees to improve their conditions. Individualist approaches to escaping social exclusion through personal employment, which dominated the approaches of Labour governments from 1997 (Steinert, 1999: 61), contributed to unrealistic expectations of volunteering leading to employment. In the refugee sector, funding has always been inadequate to provide a paid post for everybody who volunteers (Evelyn Oldfield Unit, 2004: 7), and what paid work is available is often below refugees' levels of skills, experience and qualifications (Wilson and Lewis, 2006: 39). Gowan (2010) shows that where people lack material resources and face structural constraints on employment, even where they have a wealth of social connections these do not necessarily translate into increased opportunities. In many cases for refugees I interviewed in Newcastle, volunteering even failed to provide 'escape' for individual refugees, but still contributed to individualist responses based on expected future positions.

Furthermore, refugees' accounts suggested potential for volunteering to increase divisions, between a well-connected, but largely unaccountable, minority of volunteers and an excluded majority of users. This echoes Skidmore et al. (2006: ix-xi), whose research in two 'deprived' neighbourhoods found governance structures tending towards intensive involvement by a minority who volunteered, able to use their connections to make further connections while often remaining unaccountable to wider communities, 
This is the accepted version of an article published in the peer-reviewed journal Critical Sociology, doi:10.1177/0896920514526623. For the version of record visit:

http://crs.sagepub.com/content/early/2014/06/02/0896920514526623?papetoc

while a number of factors contributed to exclude new people. Volunteering can also contribute to social control by the state, facilitating a process of 'transformismo', 'describing the capacity of the hegemonic bloc to "cream off" opposition leaders' (Davies, 2011: 106-8). When comparing the trajectories of voluntary activity among refugees I interviewed, one of the most striking patterns is the frequency with which forms of activity diversified over time, for example setting up a women's RCO while also volunteering with a young offenders' project, indicating a tendency for voluntary activity to open up opportunities for other forms of action, and increase the likelihood of volunteers taking up these opportunities. Whether these multiple connections are directed toward individual advancement or collective liberation is influenced by an individual's class position, mediated by their subjective understanding of their longer-term class trajectory.

\section{The impact of self-predicted class trajectories}

Refugees who occupied middle- or upper-class positions in their country of origin are disproportionately represented, both among those making it to Britain (Stewart, 2008: 225-6), and among those undertaking voluntary activity (WLRI, 2005: 34), despite workingclass living conditions and employment within Britain (RRF, 2011); this was also reflected among the refugees I interviewed. Going some way to explain this, some refugees' accounts of how they began volunteering suggested greater confidence and higher levels of education, including language skills, may be important factors equipping such individuals to perform voluntary roles, and such attributes may be expected to be more common among refugees from more privileged backgrounds.

Although accounts of a downward class trajectory following forced flight were common among interviewees, many also expressed a subjective belief that their longer-term trajectory was a middle-class one, and that their present position was a temporary deviation. A focus group participant who had secured status illustrated the force of 
This is the accepted version of an article published in the peer-reviewed journal Critical Sociology, doi:10.1177/0896920514526623. For the version of record visit:

http://crs.sagepub.com/content/early/2014/06/02/0896920514526623?papetoc

aspirations in shaping their priorities, even where there was no imminent prospect of fulfilling these:

The last time I was in the job centre I went to see the...key worker...and she was saying to me 'Ah, you see, what kind of job you want to do', and I said no, it's not that I don't want to work, but I don't want the kind of job you want me to do...it's not insulting people, but l've been someone in my country, I studied...I want to do education in this country...because I don't want my kids seeing me all the time moaning, being unable to offer them even the tiny things that they're asking me...You think that is good, if I can do cleaning job, but...I've got ambition...I don't think I will be able to fulfil all my children's desires (DRC, former professional, female)

This illustrates the complex combination of factors intervening between this individual's current working-class position and the forms of action they prioritise, including: status in their country of origin ('I've been someone'); educational attainment ('I've studied'); image in front of family members ('my kids seeing me all the time moaning'); desire to meet dependents' needs ('I don't think I will be able to fulfil all my children's desires'); and self-confidence and aspirations ('I've got ambition'). They are careful to make clear that they are not looking down on people doing a 'cleaning job', but it is not the type of work they are prepared to identify themselves with. Such aspirations create pressure to engage in social capital formations linking with those in positions of greater power, in relationships that prioritise individual advancement above the collective situation of refugees. Another focus group participant confirmed this role of volunteering for many refugees, to 'prove oneself', in order to gain recognition from people who might grant access to middle class employment:

[T] hey may ask what kind of reference do you have, and you say you are a doctor, [but] who knows that you are a doctor, which country are you from? If you are not involved in the voluntary sector where people say ok, they had a chance to see there is some 
This is the accepted version of an article published in the peer-reviewed journal Critical Sociology, doi:10.1177/0896920514526623. For the version of record visit:

http://crs.sagepub.com/content/early/2014/06/02/0896920514526623?papetoc

potential in this individual (DRC, former professional, male)

Where refugees come from a more privileged class background and anticipate resuming such a position in the future, their activities may reflect this perceived trajectory rather than their immediate position. This is a further deterrent against siding with other refugees in a collective struggle against the state, encouraging instead individual cooperation with the state, despite an acute awareness of its actions to the detriment of refugees.

Refugees' perceptions of their likely future class trajectory, and which set of interests they prioritise in the light of this, are fundamentally related to questions of political consciousness and the balance of class forces that influence the likely outcomes of their actions, with the state playing a central role.

\section{The community and the state}

Despite shared material conditions, there was substantial evidence of continuing racialised divisions on a subjective level within geographical localities, as a refugee described:

British people come here...some of them are no good...the way they talk, their body language, you notice that something is happening, maybe some of them doesn't like black people, we know it...we...try to ignore it (COM volunteer 4) Despite the prominence given to 'community' in much social capital theorizing, such accounts suggest it may be inadequate by itself as a basis for collective action and empowerment. Frequently 'the community' is heavily penetrated by the state, impregnated with its values, and divided along multiple lines. Some interviewees linked experiences of individual racism within the community directly to the policies of the British government, which they saw as dividing refugees from British people in order to undermine any potential for joint resistance:

[The British government] don't want [refugees without status] to learn English, they 
This is the accepted version of an article published in the peer-reviewed journal Critical Sociology, doi:10.1177/0896920514526623. For the version of record visit:

http://crs.sagepub.com/content/early/2014/06/02/0896920514526623?papetoc

don't want people to make friends with local people, so it's easy for them to do everything they want to do to them (CAMP volunteer 6)

This is reinforced by a briefing paper (Rea 2010), issued by the head of the Asylum, Refugee and Migration Services of Manchester City Council and leaked publicly, citing the difficulties posed for deportations by 'community protest on the day of removal', media campaigns and lobbying, all of which they suggest are encouraged by housing refugees in mixed residential areas instead of detention.

Das (2006) argues that there is potential for working-class social capital at the macro level that connects working-class people to pro-worker reformists among state officials, who are embedded in local working-class communities and can help obtain concessions, although he also points to contradictions and limits within this (78-80). Similarly, my study found that voluntary and community sector organizations where refugees volunteered brought concessions for individuals while carrying contradictions and limits. Social capital formations connected sections of the state, voluntary and community sector organizations, and refugees as volunteers and users. Williams et al. (2013) point to the ways in which migrants' values both influence the migration process and are shaped by the experience of migration. In this case, at the same time as refugees helped individuals by volunteering, they also aided the state to implement policies that were detrimental to refugees, by using their trust in one another to encourage cooperation with its procedures. By volunteering with organizations such as VOL, and to some extent COM and CHUR, that operated in partnership with the British state, ${ }^{3}$ refugees provided solidarity and understanding to other refugees based on shared experiences, helping some individuals to get a 'better deal' within the constraints of the asylum system. This was an important part of the incentives to volunteer reported by all the refugees I interviewed. Yet the norms and values of social capital formations engaging refugees with the asylum system were dominated by the state, which placed no trust in refugees but demanded total compliance 
This is the accepted version of an article published in the peer-reviewed journal Critical Sociology, doi:10.1177/0896920514526623. For the version of record visit:

http://crs.sagepub.com/content/early/2014/06/02/0896920514526623?papetoc

(Hynes, 2009), within a system that individualised each refugee as a 'case', undermining possibilities for resistance on the basis of refugees' collective oppression. Furthermore, the depoliticized provision of basic services to help refugees survive, resourced to $s$ significant extent through refugees' unpaid labour, stabilized the asylum system by softening the impact of hardships caused by a lack of state support, thus provoking less resistance (a situation with increasingly wide relevance as working-class communities face the current austerity measures). As Woolford and Curran (2012: 53-4) note, neo-liberal reductions in resources for welfare providers place these services under such pressure to meet immediate needs that their capacity to challenge structural causes of social problems are further curtailed. The voluntary activity of refugees thus helped diffuse conflicts arising from the contradictions between refugees and the state, by using social capital between refugees as volunteers and refugees as users to impose a nationalcapitalist hegemony of practice, if not of ideas.

This picture resonates with critiques of 'linking' capital (Griffiths, et al., 2005: 33), which suggest engagement with the powerful may at most allow a few fortunate individuals to 'get ahead' (Wilson and Lewis, 2006: 16), while deflecting challenges to collective oppression. Hampton's (2010) research on a socially and ethnically diverse youth volunteering programme in the US suggests that even where members of an oppressed group form more connections across racial and educational divides, it may be those who are already the most privileged that gain most from volunteering in the sense of new connections that help them to 'get ahead' even further, increasing inequalities. In my research, in some cases roles with funded organizations created divisions between refugees as volunteers and other refugees. At VOL, this took the form of other refugees identifying the organization and its volunteers with the state because they were contracted to provide the first point of contact with the Home Office, as a volunteer described: '[W]hen you were a client...you honestly do see these people who work here as 
This is the accepted version of an article published in the peer-reviewed journal Critical Sociology, doi:10.1177/0896920514526623. For the version of record visit:

http://crs.sagepub.com/content/early/2014/06/02/0896920514526623?papetoc

an enemy' (VOL volunteer 2). Thus the role of refugees in VOL, volunteering at the interface between the state and other refugees, weakened the very bonds of trust that encouraged other refugees to engage with them. This resulted in social capital formations which connected refugees as users to the state through refugees as volunteers, in a relationship whose norms and values were determined overwhelmingly by the state and which served to reinforce capitalist hegemony in practice, even if many volunteers remained highly critical of the state at the level of ideas. One volunteer expressed the contradiction at the heart of VOL's role, of supporting and helping migrants at the same time as servicing a system which oppresses them, reflected th the level of consciousness. On the one hand, they recognised Britain's reliance on migrants for their labour and their super-exploited position:

The cheap job, the shitty job, and they're all [being done by] migrants, I mean the British people would not do that, I mean they need migrants ... England's been built on migrants. (VOL volunteer 4)

Yet immediately following this, they spoke about the majority of those claiming asylum in Britain in extremely derogatory terms, discounting the basis for the majority of refugee claims in advance and blaming them for the oppression faced by 'genuine' refugees:

[Refugees are] coming in Sangatte [refugee camp] in France, which is European country, thousands, thousands...If they want their safety, if they really have a problem in their country, human rights law and the 1951 policy, they say if you're in your third country you have to claim asylum, where the life is safe for you...80 per cent of people coming here for work, for the things that they can't do in their countries, to support their family, to do other things, and 20 per cent of people they have problems. If I give you an example, it's a glass of water, if you [put a] bit of dirty water in there it all becomes dirty...All people are going in one name, and the water, you cannot split it. So that's the reason they want to do their law 
This is the accepted version of an article published in the peer-reviewed journal Critical Sociology, doi:10.1177/0896920514526623. For the version of record visit:

http://crs.sagepub.com/content/early/2014/06/02/0896920514526623?papetoc

tougher and harder, to show to the people their rules.

To some extent this was also the case for COM and CHUR; their greater independence from the state enabled wider contestation of the terms of engagement and the nurturing of norms and values based on collective mutual aid solutions, but these did not pose a direct threat to ruling class hegemony and instead accepted the system and tried to help one another survive it.

Social capital formations can be viewed as both the social networks and structures through which refugees and others pursue their goals, and through their norms and values impacting back on the consciousness of individuals, shaping their future actions. Volunteering has potential to incorporate volunteers, and through them project users, within social capital formations that are dominated by the state and reinforce capitalist hegemony, or alternatively to produce oppositional social capital formations that can support challenges to the state. 
This is the accepted version of an article published in the peer-reviewed journal Critical Sociology, doi:10.1177/0896920514526623. For the version of record visit:

http://crs.sagepub.com/content/early/2014/06/02/0896920514526623?papetoc

\section{Conclusion}

The findings presented here demonstrate the contradictory role of volunteering within refugees' consciousness and actions at an individual level. Whilst individual experiences and actions possess a degree of randomness, in the relation between them at the level of the social, mediated by consciousness, the actions and experiences of individuals connect to historical processes, and a quantity of individuals undergo a qualitative change to mass social forces (Lenin, [1895-1916] 1972: 123-4). As part of this process, social capital formations are a way of conceptualising processes mediating between individuals' material interests, group membership, and their actions, shaping how they see their interests and their relation to the interests of others. The hegemony of capitalist ideas may shape and be sustained through social capital formations, in a dialectical relationship. Despite spontaneous tendencies toward more collective forms of identity within refugee volunteering, asylum policies including dispersal, the prohibition on paid work, and decision-making processes based on each individual's asylum case, combined with the state's penetration into working-class localities and into the organizations with which many refugees volunteer, to reinforce perceived connections between volunteering and paid employment and the expectation among many refugees that their long-term trajectory was middle-class, in spite of current objective conditions, encouraging individualized forms of action. For the majority, this lead to the continuation of a subordinate position.

The limitations of apolitical voluntary activity among refugees to cultivate oppositional social capital as a basis for resistance to the state, which have been demonstrated here, are consistent with the Leninist analysis of spontaneity (Lenin, [1902] 1978). They also support Livingstone's (2013: 352) conclusion, that:

The state, and the festishised commodification of charity and of labour through volunteering, reproduce the particular capitalist social form of charity...to 
This is the accepted version of an article published in the peer-reviewed journal Critical Sociology, doi:10.1177/0896920514526623. For the version of record visit:

http://crs.sagepub.com/content/early/2014/06/02/0896920514526623?papetoc

participate in charity is already to participate in the displacement of struggle, in struggles that are mediated in a way that is never completely transformative. Although capitalist hegemony is never absolute, and as has been shown here the contradictions arising from capitalist oppression repeatedly break through, overcoming the limitations of such spontaneity may require greater emphasis on hegemony in the sense of political working-class leadership. Realising the potential within refugees' volunteering to foster oppositional social capital as a basis for collective resistance may require a political intervention to draw out the conscious element within every spontaneous action, to develop a scientific understanding that does not contradict volunteers' personal experiences but deepens them by placing them within a historical and systemic understanding, that can inform a critical distance from the state (Lenin, [1893-1923] 1972: 474; an example of such an approach is discussed in Vickers 2014).

In the current context of austerity measures and a policy approach that is increasingly hostile to immigration, evident in the 'cap' on annual migration and restrictions on migrants' access to housing, healthcare and education, contradictions seem likely to intensify between the state and the working classes in general, and refugees and other migrants from oppressed countries in particular (discussed in more detail in Vickers 2012). These intensifying contradictions increase the significance of processes of social control and resistance such as those described here and call for efforts by Marxist sociologists to unmask them in order to reveal the potential and limits for their disruption. Volunteering has also figured prominently within the discourse of the Coalition government which came to power in 2010, enmeshed in the 'Big Society' agenda, as both a supposed substitute for services that are being cut and a means of social control, and therefore continues to be an important field for analysis and struggle. 
This is the accepted version of an article published in the peer-reviewed journal Critical Sociology, doi:10.1177/0896920514526623. For the version of record visit:

http://crs.sagepub.com/content/early/2014/06/02/0896920514526623?papetoc

\section{Notes}

${ }^{1}$ The British state employs categories of 'asylum seeker' to refer to those who have applied for refugee status but have not yet had their cases decided, 'refugee' to refer to those who have been given some form of leave to remain, and 'refused asylum seeker' to refer to those who have had their cases refused. As a consequence of appeals and new evidence an individual may move back and forth between the first and third categories. Due to the mistrust and stigmatization associated with the term 'asylum seeker' (Dummet, 2001), I use 'refugee' to encompass all those who have come to Britain seeking refuge, and where relevant specify whether an individual is with or without 'status', in the sense of refugee status or some form of leave to remain in Britain and access employment and the same statutory services as British citizens.

${ }^{2}$ A policy approach characterized by aggressive privatization and deregulation, representing in Marxist terms an attempt to break down legal, social and political barriers to multinational capitals moving anywhere in the world in pursuit of profits, and to transform new aspects of human life and the natural environment into sources of surplus value. In pursuit of this end, neo-liberalism has engaged in social interventions in order to 'equip the poor for their incorporation into and subjection to competitive labour markets and the creation of an institutional framework within which global capital accumulation can be sustained, while simultaneously seeking to legitimate the project through participation and a pro-poor agenda' (Cammack, 2004: 190; also O'Connor 2010). Social capital theory and the interventions it has informed have been part of this legitimation process.

${ }^{3}$ VOL most directly through delivery of Home Office contracts, CHUR and COM through contact with the Home Office at some distance and more directly with neighbourhood police. CAMP also engaged with the state at multiple levels, but in an adversarial and sporadic way that left little space for developing trusting relationships. 
This is the accepted version of an article published in the peer-reviewed journal Critical Sociology, doi:10.1177/0896920514526623. For the version of record visit:

http://crs.sagepub.com/content/early/2014/06/02/0896920514526623?papetoc

\section{References}

6 P, Fletcher-Morgan C and Leyland K (2010) Making people more responsible: the Blair governments' programme for changing citizens' behaviour. Political Studies 58(3): 427-449. Anthias F (2007) Ethnic ties: social capital and the question of mobilisability The Sociological Review 55(4): 788-805.

Body-Gendrot S and Gittell M (2003) Empowering citizenship to social capital. In BodyGendrot S and Gittell M (eds) Social Capital and Social Citizenship. Lanham MD: Lexington Books.

Bourdieu P (1995) Sociology in Question. London: Sage.

Briskman L and Cemlyn S (2005) Reclaiming humanity for asylum-seekers: A social work response. International Social Work 48(6): 714-724.

Cammack P (2004) What the World Bank means by poverty reduction, and why it matters. New Political Economy 9(2): 189-211.

Crawley H, Hemmings J and Price N (2011) Coping with destitution: Survival and livelihood strategies of refused asylum seekers living in the UK. Swansea: Swansea University and Oxfam.

Cuthill F, Abdalla OS and Bashir K (2013) Between destitution and a hard place: Finding strength to survive refusal from the asylum system: a case study from the North East of England. Sunderland: University of Sunderland.

Das RJ (2006) Putting social capital in its place. Capital and Class 30(3): 65-92.

Davies JS (2011) Challenging Governance Theory: From networks to hegemony. Bristol:

Policy Press.

Devine F and Roberts JM (2003) Alternative approaches to researching social capital: a comment on van Deth's measuring social capital. International Journal of Social Research Methodology 6(1): 93-100.

Dummet M (2001) On Immigration and Refugees. London: Routledge. 
This is the accepted version of an article published in the peer-reviewed journal Critical Sociology, doi:10.1177/0896920514526623. For the version of record visit:

http://crs.sagepub.com/content/early/2014/06/02/0896920514526623?papetoc

Evelyn Oldfield Unit (2004) Refugee Volunteering: Integration in action, report of a national conference. London: Evelyn Oldfield.

Fine B (2010) Theories of Social Capital: Researchers behaving badly. London: Pluto Press. Foster JB, McChesney RW and Jonna RJ (2011) The global reserve army of labor and the new imperialism. Monthly Review 11(1): 1-31.

Furbey R, Dinham A, Farnell R, Finneron D, and Wilkinson G. (2006) Faith as Social Capital: Connecting or dividing?. Bristol: Policy Press.

Gillespie M (2012) Trapped: destitution and asylum in Scotland. Glasgow: Scottish Poverty Information Unit.

Gilroy P (2001) Against Race: Imagining political culture beyond the color line. Cambridge MA: The Belknap Press of Harvard University Press.

Gowan T (2010) What's social capital got to do with it? the ambiguous (and overstated) relationship between social capital and ghetto underemployment. Critical Sociology 37(1): 47-66.

Gramsci A ([1929-1935] 1982) Selections from the Prison Notebooks. London: Lawrence and Wishart.

Griffiths D, Sigona N and Zetter R (2005) Refugee Community Organizations and Dispersal: Networks, resources and social capital. Bristol: The Policy Press. Hampton LA (2010) Covert racism and the formation of social capital among a Volunteer Youth Corps. Critical Sociology 36(2): 285-305.

Hardill I, Baines S and 6 P (2007) Volunteering for all? explaining patterns of volunteering and identifying strategies to promote it. Policy and Politics 35(3): 395-412.

Healy G, Bradley H and Mukherjee N (2004) Individualism and collectivism revisited: a study of black and minority ethnic women. Industrial Relations Journal 35(5): 451-466. Hynes P (2009) Contemporary compulsory dispersal and the absence of space for the restoration of trust. Journal of Refugee Studies 22(1): 97-121. 
This is the accepted version of an article published in the peer-reviewed journal Critical Sociology, doi:10.1177/0896920514526623. For the version of record visit:

http://crs.sagepub.com/content/early/2014/06/02/0896920514526623?papetoc

John P, Fieldhouse $\mathrm{E}$ and Liu $\mathrm{H}$ (2011) How civic is the civic culture? explaining community participation using the 2005 English Citizenship Survey. Political Studies 59(2): 230-252. Jones C and Novak T (1999) Poverty, Welfare and the Disciplinary State. London: Routledge.

Lavalette M (ed) (2011) Radical Social Work Today: Social work at the crossroads. Bristol, The Policy Press.

Lenin VI ([1895-1916] 1972) Philosophical Notebooks. London: Lawrence and Wishart. Lenin VI ([1902] 1978) What is to be Done?. Peking: Foreign Language Press.

Lenin VI ([1916] 1975) Imperialism, the Highest Stage of Capitalism. Moscow: Progress Publishers.

Lenin VI ([1917] 1972) The State and Revolution. Moscow: Progress Publishers. Lewis H, Dwyer P, Hodkinson S and Waite L (2013) Precarious Lives: Experiences of forced labour among refugees and asylum seekers in England. Leeds: University of Leeds. LEWRG London Edinburgh Weekend Return Group (1980) In and Against the State. London: Pluto Press.

Livingstone N (2013) Capital's charity. Capital \& Class 37(3), 347-353.

Marx K and Engels F ([1845] 1991) The German Ideology. London: Lawrence Wishart. Mayer M (2003) The onward sweep of social capital: causes and consequences for understanding cities, communities and urban movements. International Journal of Urban and Regional Research 27(1): 110-132.

McLellan D (1980) Marxism After Marx. London: MacMillan.

Mills J and Robson S (2010) Does community organizing empower or oppress?. $c d x$ magazine Winter 2010: 12-14.

Morisen J (2000) The government-voluntary sector compacts: governance, governmentality, and civil society. Journal of Law and Society 27(1), 98-132. O'Connor J (2010) Marxism and the three movements of neoliberalism. Critical Sociology 
This is the accepted version of an article published in the peer-reviewed journal Critical Sociology, doi:10.1177/0896920514526623. For the version of record visit:

http://crs.sagepub.com/content/early/2014/06/02/0896920514526623?papetoc

36(5), 691-715.

Papadopoulosa D and Tsianosb VS (2013) After citizenship: autonomy of migration, organisational ontology and mobile commons. Citizenship Studies 17(2), 178-196.

Però D (2008) Political engagement of Latin Americans in the UK: issues, strategies, and the public debate. Focaal: European Journal of Anthropology. 51: 73-90.

Petras J and Veltmeyer H (2001) Globalisation Unmasked: Imperialism in the 21st Century. Delhi: Madhyam Books.

Portes A (1998) Social capital: its origins and applications in modern sociology. Annual Review of Sociology 24: 1-24.

Putnam RD (2000) Bowling Alone. New York: Simon and Schuster.

Rea N (2010) Alternatives to Detention for Asylum Seeking Families, Subject to Removal. Briefing paper to members of the North West Consortium. Manchester City Council. Reed J-P (2013) Theorist of subaltern subjectivity: Antonio Gramsci, popular beliefs, political passion, and reciprocal learning. Critical Sociology 39(4), 561-591.

Roberts JM (2004) What's 'social' about 'social capital'?. British Journal of Politics and International Relations 6(4): 471-493.

RRF (2011) Finding routes for Refugees to use their skills and experience and contribute to the North East region's economic future. Gateshead: Regional Refugee Forum North East. Shaw M and Martin I (2000) Community work, citizenship and democracy: re-making the connection. Community Development Journal 35(4): 401-413.

Shucksmith M (2000) Endogenous development, social capital and social inclusion: perspectives from LEADER in the UK. Sociologia Ruralis 40(2): 208-218.

Skidmore P, Bound K and Lownsbrough H (2006) Community participation: Who benefits?. York: Joseph Rowntree Foundation/DEMOS.

Steinert H (1999) Social Exclusion as a Multidimensional Process. Vienna: Institut für Rechts- und Kriminalsoziologie. 
This is the accepted version of an article published in the peer-reviewed journal Critical Sociology, doi:10.1177/0896920514526623. For the version of record visit:

http://crs.sagepub.com/content/early/2014/06/02/0896920514526623?papetoc

Stevenson $G$ (1978) Social relations of production and consumption in the human service occupations. International Journal of Health Services 8(3), 453-463.

Stewart $E$ (2008) Exploring the asylum-migration nexus in the context of health professional migration. Geoforum 39: 223-235.

Temple B and Moran R (2005) Learning to Live Together: Developing communities with dispersed refugee people seeking asylum. York: Joseph Rowntree Foundation.

Vickers T (2012) Refugees, Capitalism and the British State: Implications for social workers, volunteers and activists. London: Ashgate.

Vickers T (2014) Developing an independent anti-racist model for asylum rights organizing in England. Ethnic and Racial Studies 37(8).

Williams NE, Thornton A and Young-DeMarco LC (2013) Migrant values and beliefs: How are they different and how do they change?. Journal of Ethnic and Migration Studies. Epub ahead of print 6 September 2013. DOI: 10.1080/1369183X.2013.830501.

Wilson R and Lewis $\mathrm{H}$ (2006) A Part of Society: Refugees and asylum seekers volunteering in the UK. Leeds: Tandem Communications and Research.

Woolcock M (1998) Social capital and economic development: toward a theoretical synthesis and policy framework. Theory and Society 27(2): 151-208.

Woolford A and Curran A (2012) Community positions, neoliberal dispositions: managing nonprofit social services within the bureaucratic field. Critical Sociology 39(1), 45-63. WLRI (2005) Women Refugees: From volunteers to employees. London: Working Lives Research Institute.

Yaffe H (2009) Che Guevara: The Economics of Revolution. Basingstoke: Palgrave MacMillan. 